\title{
三番茶摘採の有無が秋芽の生育と翌年一番茶に及ぼす影響*
}

\author{
長崎県総合農林試験場東彼杵茶業支場** \\ 森山新三郎・㴊 通 則 \\ (平成 10 年 3 月 20 日受理)
}

\section{Influences of Plucking or not of the Third Crop Tea on the Growth of Autumn Shoots and the First Crop of Tea in the Next Year}

\author{
Shinzaburo MorIYAma and Michinori FuCHI \\ Higashi-Sonogi Tea Branch, Nagasaki Agricultural and Forestry Experiment Station
}

\section{Summary}

The management technique of tea trees in order to take the stable yield of the first crop in the next year was examined by influences of plucking or not of the third crop, shapes of autumn shoots, and the vitality of shoot.

The yield of the first crop in the next year in a field of the medium pruning differed in plucking or not of the third crop. Taking the above yield of the first crop in the next year, it seemed proper that plucking of the third crop was carried out in 3 years, non plucking of the third crop had better do 4-5 years after, and non plucking of the third crop 6 years after, furthermore. On the other hand, the first crop in the next year was lots of yield by plucking of the third crop in a field which has undergone light and deep trimmings after the second crop.

In case of immediately after the medium pruning, shape of autumn shoots was large, and regenerated new shoots of the first crop were many after pruning of new shoots. However, it would rather be treated in a medium pruning field passed several years by non plucking of the third crop.

It is presumed that the vitality of shoot will become weak year by year after the previous medium pruning. Therefore, it is desirable to pluck or not of the third crop by the interval from the previous mediuma pruning.

\section{1 緒言}

近年の茶園は, 優良品種の普及や肥培管理
技術の高位平準化，さらに気象災害対策等の 整備により生産力は年々向上している。しか し，最近の傾向として夏茶の価格低迷により

* 本報告の一部梳平成 8 年度九州農業研究発表会に扔いて発表した。

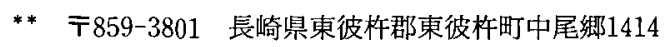


翌年の一番茶に期待し, 二番茶の早摘み, 浅 摘み，三番茶は摘採を中止する場面が多くな っている。

この結果，茶芽の生育が良好となる茶園と 過繁茂になる茶園が見られる。秋芽が伸び過 ぎた茶園では，整枝作業が困難となるばかり でなく，翌年一番茶の生葉収量が思うほど上 がらず，茶品質も劣る事例が多い，そこで, 茶園によって三番茶摘採の有無の判断基準が 必要と考えてこの試験を行った。その結果, 茶樹の更新経歴で枝条活力が異なり，三番茶 摘採の可否は更新の経歴で推測できると思わ れたので，ここにその結果を報告する。

\section{2 材料および試験方法}

試験地の東彼杵茶業支場は, 標高 $380 \mathrm{~m}$ に位 置し, 年平均気温は $13.2^{\circ} \mathrm{C}$, 年間降水量は約 $2,500 \mathrm{~mm}$ で，土裹は玄武岩を母材とする造成 地，細粒赤土〜黄色土である。年間 $10 \mathrm{a}$ 当た り $\mathrm{N}-75 \mathrm{~kg}, \mathrm{P}_{2} \mathrm{O}_{5}-38 \mathrm{~kg}, \mathrm{~K}_{2} \mathrm{O}-38 \mathrm{~kg}$ の施 肥と堆厩肥 $2,000 \mathrm{~kg}$ の投入を毎年行っている 茶園を供試した。品種は全ての試験で“やぶ きた”を用いた。

なお，試験期間中の1992年, '93年に凍霜害, ’94年，’95年に干ばつが発生した。

試験 1 中切り後の茶園における三番茶摘採 の有無と翌年一番茶芽の生育

1984年 5 月に樹齢16年生で中切り更新処理 した茶樹を用い, 更新後 6 年目の 1989 年 5 月 に前回更新面より上で再度中切り更新を行っ た。更新当年は 7 月下旬に中切り面で再生芽 をせん除し，翌年（1990年）の更新処理 2 年 目から，一，二番茶を摘採し，三番茶につい て摘採 (各年とも萌芽期から12日目に摘採) する区と摘採しない区を 1 区 $9.9 \mathrm{~m}^{2}, 2$ 反復 設けた。調査は, 秋整枝量と翌年一番茶の生 育および生葉収量について行った。

試験 2 中切り後の経過年数の違いによる秋 枝の形状と新芽再生

1989年 5 月に樹踰15年生で中切り更新処理 し, 1995年に再度中切り更新した茶樹を用い, 中切り更新 7 年樹と翌年樹（いずれも樹龄22 年生）の秋整枝面の枝条について比較した。
一番茶の通常の摘採および枠摘み調查は 5 月 10日（1996年）に行った。また, 再生芽の調 查は, 茶畦の東, 中央, 西側に $20 \times 20 \mathrm{~cm}$ 枠を 設置し，秋整枝面加葉層 $5 \mathrm{~cm}$ 内の全新芽を 一番茶萌芽期直後に芽の基部から除去し，そ の後再生した芽の萌芽期から約 1 ケ後に, 秋 整枝面上に伸びた芽を $1 \mathrm{~cm}$ 以上の有効芽と以 下の無効芽に分け，3反復で比較調査した。

試験 3 二番茶後の更新園に扔ける三番茶の せん除と翌年一・二番茶芽の生育

1990年 5 月に樹齢 17 年生で再度中切り更新 を行い，その後更新 4 年樹（1994年）と 5 年 樹（1995年）の二番茶摘採後に浅刚り ( -9 $\mathrm{cm})$ および深刚り $(-16 \mathrm{~cm})$ 更新処理した区 を設け,さらに, 三番茶不摘採, 三番茶摘採 区と比較した。試験区はそれぞれ 1 区 $9.9 \mathrm{~m}^{2}$ の 2 反復とし, 調查は, 三番茶のせん除量と 秋整枝量および翌年一・番茶の生育と生葉 収量について行った。

\section{3 結果}

試験 1 中切り後の茶園における三番茶摘採 の有無と翌年一番茶芽の生育

三番茶の摘採量は年次間で変動があり, 特 に 6 年目（1994年）は干ばつの影響で少なか った。秋整枝量は更新後の経過年数に従い, 三番茶不摘採区は減少する傾向が認められ た。摘採区は凍霜害や秋期の乾燥等気象の影 響が大きく作用し，一定の傾向は見られなか った。

中切り更新後の一番茶の経年変化を見る と, 中切り更新後 3 年目は百芽重の差は小さ く,茅数の多い摘採区の生葉収量が多かった。 4 年目は凍霜害で全体に生葉収量が少なく, 処理間では摘採区の芽数が多かったが, 百芽 重の大きい不摘採区の生葉収量がやや多かっ た。 5 年目は凍霜害が甚大で, 芽数, 百芽重 とも大幅に減少し, 生葉収量は少なく, 処理 間では不摘採区の百芽重がやや大きく生葉収 量が多かった。6 年目から防霜ファンを設置 したため生産は安定し, 処理間では摘採区の 芽数が多かったが, 不摘採区の百芽重が大き く生葉収量が多かった。なお，この年 (1994 
(茶研報87：1～6, 1999)

年）は夏から秋にかけて干ばつが発生し，三 番茶芽, 秋芽とも生育不良であった。7 年目 は前年の干ばつの影響を受けたと思われ，特 に,摘採区の百芽重が不摘採区に比べ小さく，
さらに，芽数の差が接近したため，百芽重の 大きい不摘採区の生葉収量が多く，三番茶摘 採，不摘採の影響が顕著に現れた（表 1 ）。

表 1 中切り茶樹における三番茶摘採の有無が秋整枝量および翌年一番茶に与える影響 $\quad(n=2)$

\begin{tabular}{|c|c|c|c|c|c|c|c|}
\hline 区 別 & 中切り経過年数 & $\begin{array}{l}2 \text { 年目 } \\
(1990)\end{array}$ & $\begin{array}{c}3 \text { 年目 } \\
\text { ('91) }\end{array}$ & $\begin{array}{c}4 \text { 年目 } \\
(' 92)\end{array}$ & $\begin{array}{c}5 \text { 年目 } \\
\text { ('93) }\end{array}$ & $\begin{array}{c}6 \text { 年目 } \\
(' 94) \\
\end{array}$ & $\begin{array}{c}7 \text { 年目 } \\
\text { ('95) }\end{array}$ \\
\hline $\begin{array}{l}\text { 三 番 茶 } \\
\text { 摘 採 量 }\end{array}$ & 三番茶摘採区 & $\begin{array}{l}270 \\
(74)\end{array}$ & $\begin{array}{l}560 \\
(91)\end{array}$ & $\begin{array}{l}260 \\
(63)\end{array}$ & $\begin{array}{l}460 \\
(88)\end{array}$ & $\begin{array}{c}90 \\
(31)\end{array}$ & - \\
\hline$(\mathrm{kg} / 10 \mathrm{a})$ & 三番茶不摘採区 & - & - & - & - & - & - \\
\hline 秋整枝量 & 三番茶摘採区 & 400 & 130 & 220 & 270 & 100 & - \\
\hline$(\mathrm{kg} / 10 \mathrm{a})$ & 三番茶不摘採区 & 510 & 380 & 390 & 290 & 150 & - \\
\hline 一番茶百芽重 & 三番茶摘採区 & - & 35 & 25 & 18 & 33 & 25 \\
\hline (g) & 三番茶不摘採区 & - & 36 & 35 & 21 & 44 & 41 \\
\hline 一番茶芽数 & 三番茶摘採区 & - & 1590 & 1780 & 650 & 2170 & 1720 \\
\hline$\left(\right.$ 本 $\left./ \mathrm{m}^{2}\right)$ & 三番茶不摘採区 & - & 1280 & 1200 & 690 & 1620 & 1670 \\
\hline $\begin{array}{l}\text { 二番 茶 } \\
\text { 生葉収量 }\end{array}$ & 三番茶摘採区 & - & $\begin{array}{l}520 \\
(56)\end{array}$ & $\begin{array}{l}370 \\
(70)\end{array}$ & $\begin{array}{l}200 \\
(51)\end{array}$ & $\begin{array}{l}700 \\
(84)\end{array}$ & $\begin{array}{l}540 \\
(46)\end{array}$ \\
\hline$(\mathrm{kg} / 10)$ & 三番茶不摘採区 & - & $\begin{array}{l}430 \\
(56)\end{array}$ & $\begin{array}{l}390 \\
(66)\end{array}$ & $\begin{array}{l}220 \\
(46)\end{array}$ & $\begin{array}{l}740 \\
(71)\end{array}$ & $\begin{array}{l}720 \\
(59)\end{array}$ \\
\hline
\end{tabular}

注）三番茶摘採日：各年とも三番茶萌芽期加ら 12 日目 ( )内：出開度 $(\%)$

凍霜害：1992、'93年 ('94年から防霜ファン設置)

干ばつ：1994、'95年

\section{表 2 中切り後の更新経過数と秋枝の形状 $\quad(n=3)$}

\begin{tabular}{|c|c|c|c|c|c|c|c|c|}
\hline $\begin{array}{l}\text { 中切り更新後 } \\
\text { の経過年数 }\end{array}$ & $\begin{array}{c}\text { 秋枝数 } \\
\left(1 \mathrm{~m}^{2} \text { 当たり) }\right.\end{array}$ & $\begin{array}{c}\text { 整枝率 } \\
(\%) \\
(\%)\end{array}$ & $\begin{array}{c}\text { 茎の太さ } \\
(\mathrm{mm})\end{array}$ & $\begin{array}{c}\text { 節間長 } \\
\text { (cm) }\end{array}$ & 節間数 & $\begin{array}{c}\text { 茎の緑色部 } \\
(\mathrm{cm})\end{array}$ & $\begin{array}{l}\text { 葉の7 } \\
\text { 葉幅 } \\
(\mathrm{cm})\end{array}$ & $\begin{array}{l}\text { きさ } \\
\text { 葉長 } \\
\text { (cm) }\end{array}$ \\
\hline 中切り翌 年 & 1,018 & 46.2 & 1.7 & 1.8 & 1.7 & 1.0 & 2.5 & 5.8 \\
\hline 中切り 7 年目 & 2,443 & 9.6 & 1.4 & 0.6 & 2.4 & 0.7 & 1.6 & 3.8 \\
\hline 有 意 性 & & $* *$ & * & $* *$ & $*$ & $*$ & $* *$ & $* *$ \\
\hline
\end{tabular}

注）調査：1996年 1 月

有意性の検定：最小有意差法で行った。 $* * （ 1 \%) \quad * （ 5 \%)$

秋枝数：秋整枝面上 $20 \mathrm{~cm} \times 20 \mathrm{~cm}$ 枠内についての枝数

整枝率 $=\frac{\text { 切除された枝数 }}{\text { 全 秋 枝 数 }} \times 100$

茎の太さ：秋整枝で切れた枝二最上葉から上位第 2 葉までの節間中央部 $\|$ 切れなかった枝=芽の先端から第 2 葉と第 3 葉の節間中央部

節間長：秋整枝で切れた枝=最上葉から上位第 2 葉までの節間長 川切れなかった枝=第 2 葉と第 3 葉の節間長

節間数： 2 葉以上着葉した枝の節間数

菱の緑色部：整枝で切れた枝は秋整枝面から，切れなかった枝は頂芽からの緑色部

葉の大きさ： 1 調査枝の健全葉で, 最も大きい葉の巾と長さ

試験 2 中切り後の経過年数の違いによる秋

枝の形状と新芽の再生

中切り更新翌年樹と更新 7 年樹の秋整枝後
に整枝面の枝条を調查した結果，翌年樹は， 秋枝数は少ないが枝の形状が大きく，整枝率 も高かった（表 2 )。 
更新翌年樹の一番茶芽の生育扔よび生葉収 量は, 無処理区では更新 7 年樹に比べ新芽数 はやや少ないものの，形状が大きいため生葉 収量が多い傾向を示した。一方，新芽を除去 した処理区を見ると, 中切り翌年樹は再生し た芽の形状が大きく,さらに, 芽数も多く, 更 新 7 年樹の処理区に比べ, 生葉収量は約 3 倍 と多かった。更新 7 年樹の新芽除去後の再生
芽は小さく，芽数は極めて少なかった(表3)。 これらの原因を解析するため秋整枝面から 葉層 $5 \mathrm{~cm}$ 内とその下から摘採面上にのびた再 生芽を調查したところ，更新翌年樹と更新 7 年樹では再生した総新芽数に有意差はない が，更新翌年樹は秋整枝面より上に伸び，摘 採機で収穫可能な芽が多く, 更新 7 年樹は弱 少芽で摘採不可能な芽が多かった（表 4 ）。

表 3 中切り更新後の経過と一番茶および新芽除去後の生育・生葉収量 $(n=3)$

\begin{tabular}{|c|c|c|c|c|c|c|c|c|c|c|}
\hline 区 & 別 & 一番茶 & 芽除去 & 調査日 & 新芽長 & 葉数 & 百芽重 & 新芽数 & 出開度 & 生葉 \\
\hline $\begin{array}{l}\text { 彻り更新後 } \\
\text { の経過年数 }\end{array}$ & $\begin{array}{ll}\text { 新 茅 } \\
\text { 除 去 }\end{array}$ & 萌芽期 & 日 & （摘採日） & (cm) & （枚） & (g) & $\left(\right.$ 本 $\left./ \mathrm{m}^{2}\right)$ & $(\%)$ & $\left(\mathrm{g} / \mathrm{m}^{2}\right)$ \\
\hline $\begin{array}{ll}\text { 切り翌 } & \text { 年 } \\
\text { 切り翌 } & \text { 年 }\end{array}$ & $\begin{array}{l}\text { 処 理 } \\
\text { 無処理 }\end{array}$ & $\begin{array}{c}4 \text { 月12日 } \\
/ \|\end{array}$ & - & & $\begin{array}{l}5.5 \\
6.1\end{array}$ & $\begin{array}{l}3.0 \\
3.1\end{array}$ & & & $\begin{array}{ll}* * & 24.7 \\
* & 49.8\end{array}$ & $\begin{array}{l}933 \\
841\end{array}$ \\
\hline $\begin{array}{l}\text { 中切り } 7 \text { 年目 } \\
\text { 中切り } 7 \text { 年目 }\end{array}$ & $\begin{array}{l}\text { 処 理 } \\
\text { 無処理 }\end{array}$ & $\begin{array}{c}\text { 月17日 } \\
\|\end{array}$ & - & $\begin{array}{l}6 \text { 月 } 6 \text { 日 } \\
5 \text { 月 } 10 \text { 日 }\end{array}$ & $\begin{array}{l}2.8 \\
4.3\end{array}$ & $\begin{array}{l}2.4 \\
3.6\end{array}$ & 42.8 & $\begin{array}{r}742 \\
1,800\end{array}$ & $\begin{array}{l}39.6 \\
40.4\end{array}$ & $\begin{array}{l}301 \\
681\end{array}$ \\
\hline
\end{tabular}

注）調查年：1996年

処理方法：一番茶萌芽期直後に新芽除去、その後再生した芽を調査

有意性の検定：処理・無処理ごとに翌年と 7 年目の検定を最小有意差法で行った。** $(1 \%) *(5 \%)$

表 4 更新経過年数と新芽除去後の再生芽数 $\left(\right.$ 本 $\left./ \mathrm{m}^{2}\right) \quad(n=3)$

\begin{tabular}{|c|c|c|c|c|c|c|c|c|c|c|}
\hline & & 有 & 効 & & & 無 & 効 & & 総 & \\
\hline $\begin{array}{l}\text { 中切り更新後 } \\
\text { の経過年数 }\end{array}$ & 母枝数 & $\begin{array}{l}\text { 葉層 } 5 \mathrm{~cm} \\
\text { 以内の母 } \\
\text { 枝加のの } \\
\text { 再生芽数 }\end{array}$ & $\begin{array}{l}\text { 葉層 } 5 \mathrm{~cm} \\
\text { 以下の母 } \\
\text { 枝加らの } \\
\text { 再生芽数 }\end{array}$ & 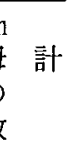 & $\begin{array}{c}\text { 対中切り } \\
7 \text { 年目比 } \\
\text { (\%) }\end{array}$ & $\begin{array}{l}\text { 葉層 } 5 \mathrm{~cm} \\
\text { 以内の母 } \\
\text { 枝加 } 50 \\
\text { 再生芽数 }\end{array}$ & $\begin{array}{l}\text { 葉層 } 5 \mathrm{~cm} \\
\text { 以下の母 } \\
\text { 枝加らの } \\
\text { 再生芽数 }\end{array}$ & 計 & 数 & $\begin{array}{l}\text { 対中切り } \\
7 \text { 年目比 } \\
\text { (\%) }\end{array}$ \\
\hline 中切り翌 年 & 858 & 1,568 & 68 & 1,636 & 209 & 480 & 0 & 480 & 2,044 & 110 \\
\hline 中切り 7 年目 & 890 & $\begin{array}{r}758 \\
* *\end{array}$ & $\begin{array}{r}25 \\
N S\end{array}$ & 783 & 100 & $\begin{array}{l}1,075 \\
\text { NS }\end{array}$ & 8 & 1,083 & $\begin{array}{l}1,866 \\
\text { VS }\end{array}$ & 100 \\
\hline 有 意 性 & NS & *** & NS & & & NS & & & NS & \\
\hline
\end{tabular}

注）調查：1996年 6 月 6 日および 9 日

有効芽：秋整枝面より $1 \mathrm{~cm}$ 上にのび摘採機で摘採可能な芽

無効芽：秋整枝面にあり摘採機て摘採不可の芽

有意性の検定：最小有意差法で行った。 **（1％）

試験 3 二番茶後の更新園に扔ける三番茶の せん除と翌年一・二番茶芽の生育

中切り更新後 4,5 年目の1994〜95年は三 番茶芽と秋芽生育期間に例年にない干ばつの 被害を被った。このような気象条件の中で, 中切り更新 4 年樹は, 三番茶不摘採区以外㹥 せん除したがその量は少なく，秋芽の生育も 不良であった。しかし，翌年一番茶は，三番 茶不摘採区および二番茶後の更新区のいずれ も, 百芽重が大きく, 生葉収量も多く, 特に
更新処理区の生葉収量が多かった。一方，中 切り更新 5 年樹は, 干ばつの影響で三番茶の 芽伸びが不良であったため，三番茶摘採区以 外はせん除を中止した。この年は秋芽の生育 期に前年より降雨が多かったため, 秋芽が過 繁茂となり秋整枝量が多くなった。しかし, 翌年一番茶の百芽重が小さく，処理間に生葉 収量の差がなく, 更新効果は認められなかっ た（表 $5-1 ， 2$ )。 
（茶研報87：1 6, 1999）

表 5-1 二番茶後の更新処理と三番茶のせん除が秋整枝量およひ翌年一・二番茶に与える影響 $(n=2)$

\begin{tabular}{|c|c|c|c|c|c|c|c|c|c|c|c|c|c|}
\hline \multirow{2}{*}{\multicolumn{2}{|c|}{ 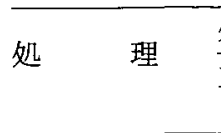 }} & \multicolumn{2}{|c|}{ 処理当年 (1994年) } & \multicolumn{5}{|c|}{ 一 番 茶 (1995年) } & \multicolumn{5}{|c|}{ 二 番 茶 } \\
\hline & & $\begin{array}{c}\text { 三番茶せん除量 } \\
(\mathrm{kg} / 10 \mathrm{a})\end{array}$ & $\begin{array}{l}\begin{array}{c}\text { 秋整枝量 } \\
(\mathrm{kg} / 10 \mathrm{a})\end{array}\end{array}$ & 摘採日 & $\begin{array}{c}\text { 百芽重 } \\
(\mathrm{g})\end{array}$ & 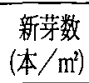 & $\begin{array}{c}\text { 出開度 } \\
(\%)\end{array}$ & $\begin{array}{l}\text { 生葉叫量 } \\
(\mathrm{kg} / 10 \mathrm{a})\end{array}$ & 摘採日 & $\begin{array}{c}\text { 百芽重 } \\
(\mathrm{g})\end{array}$ & $\begin{array}{l}\text { 新芽数 } \\
\left(\text { 本 } / \mathrm{m}^{*}\right)\end{array}$ & $\begin{array}{c}\text { 出開厚 } \\
(\%)\end{array}$ & $\begin{array}{l}\text { 生葉収量 } \\
(\mathrm{kg} / 10 \mathrm{a})\end{array}$ \\
\hline & 浅刈り & 67 & 380 & 5月17日 & 53 & 1,370 & 48 & 850 & 6月29日 & 26 & 1,350 & 46 & 400 \\
\hline & & 59 & 4 & "n & 52 & 1,210 & 51 & & " & 29 & 1,420 & 42 & \\
\hline & & - & 15 & $n$ & 41 & & 59 & & $n$ & 22 & & & \\
\hline 三 & & 90 & 100 & $m$ & 25 & 1,720 & 46 & 540 & $m$ & 22 & 1,580 & 56 & 420 \\
\hline
\end{tabular}

注）茶樹は中切り 4 年目

表 5-2 二番茶後の更新処理と三番茶のせん除が秋整枝量および翌年一・二番茶に与える影響 $(n=2)$

\begin{tabular}{|c|c|c|c|c|c|c|c|c|c|c|c|c|c|}
\hline \multirow{2}{*}{ 処 } & \multirow{2}{*}{ 理 } & \multicolumn{2}{|c|}{ 処理当年 (1995年) } & \multicolumn{5}{|c|}{ 一 番 茶 （1996年） } & \multicolumn{5}{|c|}{ 二番 茶 } \\
\hline & & $\begin{array}{c}\text { 三番茶せん除量 } \\
(\mathrm{kg} / 10 \mathrm{a})\end{array}$ & $\begin{array}{c}\text { 秋整枝量 } \\
(\mathrm{kg} / \mathrm{log})\end{array}$ & 摘採日 & $\begin{array}{c}\text { 百芽重 } \\
(\mathrm{g})\end{array}$ & $\begin{array}{l}\text { 新芽数 } \\
\left(\text { 本 } / \mathrm{m}^{2}\right)\end{array}$ & $\begin{array}{c}\text { 出開度 } \\
(\%)\end{array}$ & $\begin{array}{l}\text { 生葉収量 } \\
(\mathrm{kg} / 10 \mathrm{a})\end{array}$ & 摘採日 & $\begin{array}{l}\text { 百芽重 } \\
\text { (g) }\end{array}$ & 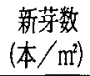 & $\begin{array}{c}\begin{array}{c}\text { 出開度 } \\
(\%)\end{array} \\
\% \text { \% }\end{array}$ & $\begin{array}{c}\text { 生葉取量 } \\
(\mathrm{kg} / 10 \mathrm{a})\end{array}$ \\
\hline & & - & 880 & & 30 & 1,300 & 46 & 550 & & 30 & 1,600 & 76 & \\
\hline & & - & 1,010 & & 46 & 1,380 & 52 & & & 26 & 1,5 & 6 & \\
\hline & & - & 420 & & 36 & 1,300 & 62 & 57 & 6月 $21 日$ & 22 & 1,430 & 75 & 400 \\
\hline & & 170 & 290 & 5月 14 日 & 29 & 2,170 & 81 & 560 & 6月26日 & 17 & 1,280 & 47 & 300 \\
\hline
\end{tabular}

注）茶樹は中切り 5 年目

干ばつ：1994、'95 年

\section{4 考察}

三番茶の不摘採園が多くなったが，生育良 好な茶園では秋芽が伸びすぎ，翌年一番茶の 収量が思うほど上がらない場面が見られる。 本研究では更新後の経歴の異なる茶樹を用い て, 三番茶摘採の有無による翌年一番茶への 影響と秋枝（母枝）の違いによる芽の再生力 について検討した。

中切り更新を行った茶樹の経年変化をみる と, 更新直後の一番茶の百芽重は, 摘採区に 比べて不摘採区が大きいが，摘採区は芽数が 多いため生葉収量が多かった。更新後 6.7 年経過すると不摘採区の百芽重が大きくな り，生葉収量が多くなった。

そこで, 更新経歴の異なる茶樹の再生力に ついて見ると, 中切り更新直後の茶樹は, 秋 整枝面の枝条数は少ないが, 枝条の形状が大 きかった。この茶樹の新芽を一番茶萌芽期直 後に全て除去し，その後再生した芽は，秋整 枝面より $1 \mathrm{~cm}$ 以上に伸びた摘採可能な芽が多 かった。一方，更新後数年経過した茶樹は， 秋整枝面の枝条数は多いが，枝条の形状が小 さく, 新芽除去後に再生した芽は摘採不可能
が多かった。このことから, 中切り更新直後 の茶樹は茶芽の再生力, つまり「枝条活力」 が強いと判断される。また, 更新後数年経過 した茶樹で三番茶の摘採を中止すると, 新芽 の形状が大きくなり生葉収量が増加すること から，枝条活力は更新後次第に低下すると推 察された。

茶芽の再生力は凍霜害発生時に茶園によっ て生葉収量に差が生じる現象で見られ, 枝条 活力の差が主な原因と考えられる。

干ばつ時の1994年に処理した二番茶摘採後 の浅・深㺫り更新区では, 生育が不良であっ たが三番茶芽をせん除した。しかし, 翌年一 番茶の百芽重が大きく,生葉収量も多かった。 三番茶芽を摘採しないと秋芽の生育が旺盛と なるが, 樹勢のある茶樹は徒長枝が多くなり， 秋芽の生育は不揃いとなる。秋芽の繁茂は一 見して樹勢があると思われるが, 過繁茂は秋 整枝作業が困難となり，さらに，このような 茶樹における秋整枝の位置は, 高くすると芽 数が確保できないため，どうしてもやや低く なりがちで, 発芽力の弱い枝条部位での整枝 となる。この結果, 翌年一番茶芽の形状が小 さく，生葉収量が少なくなると思わ机る。 
れは，秋芽が伸び過ざると翌年一番茶の収量 を構成する適正な芽の形状と芽数が得られな いと判断された。このことは, 中野ら"(1997) の三番茶摘採中止を前提とした二番茶の早摘 みや浅摘みは，秋芽が過繁茂となるため，秋 芽の生育を抑制した方が翌年一番茶の適正な 茶芽の形状と芽数が確保され, 生葉収量が多 くなる報告と, 武田ら ${ }^{2)}(1989)$ の深刈り更新 後に行う整枝は，徒長枝を抑制し芽数の増加 を図る必要がある報告と一致した。

これらの結果から, 中切り更新後 3 年目ま で, また, 二番茶摘採後に浅刈りや深刈り更 新処理した場合は, 枝条活力があるため, 三 番茶の摘採を行い秋芽の生育を抑制した方が 良く, 更新後 6 年を経過した茶樹は摘採を中 止し，秋芽の生育を旺盛にした方が良いと思 われた。

このように，整せん枝が，芽の生育や芽数 に与える影響が大きく,三番茶摘採の有無は, 更新後の経過年での枝条活力で判断する必要 がある。さらに，枝条活力を維持するために は, 樹勢が低下しないうちに地上部の更新を， 計画的 (更新効果持続年数 ${ }^{3,4}$ : 浅刈り 1 年, 深刈り 3 年, 中切り 5 年)に行う必要がある。

\section{5 摘要}

一番茶の安定多収や茶品質向上のため, 三 番茶摘採の有無が翌年の一番茶に及ほす影響 と秋枝の形状の違いによる茶芽の再生力を調 查し, 茶樹の枝条の違いによる管理技術を検 叶した。

(1)中切り更新処理した茶樹で, 三番茶摘採と 不摘採の翌年一番茶の生葉収量は, 更新 3 年目までは三番茶摘採が多く，4〜5 年目 から三番茶不摘採が多くなり，6年目以降 になるとさらに三番茶不摘採が多収となっ
た。

(2)二番茶後に浅刚り・深刈り更新処理した茶 樹において三番茶の摘採を中止したとこ ろ，秋芽が伸びすぎ，三番茶を摘採した方 が翌年一番茶の生葉収量が多かった。

(3)更新直後の茶樹と数年経過した茶樹での秋 枝の形状は，更新直後が大きく，一番茶の 新芽を除去しても，再生した芽の生育は良 好であった。このことから，更新直後の茶 樹は枝条活力があると判断される。しかし， 更新後数年経過すると枝条活力は年々低下 すると思われた。

(4)以上のことから，更新の経歴によって枝条 活力が異なるため, 三番茶摘採の可否は, 更新後の経過年での枝条活力によって判断 する必要がある。

\section{6 謝辞}

本試験を行うに当たり御協力いただいた， 長崎県総合農林試験場東彼杵茶業支場池下一 豊研究員 (現在, 長崎県江迎農業改良普及七 ンター), 森タツ子氏 (臨時職員), 並びに関 係職員に厚く御礼申し上げます。

\section{7 引用文 献}

1) 中野敬之, 井尼誠、鈴木隆之 (1997)：二 番茶の「みる芽」摘みが翌年一番茶に及 ほす影響，茶研報第85号（別冊）38～39

2 ) 武田善行, 簗瀬好充 (1989)：茶樹更新に おける最適なせん枝時期強度について， 野菜・茶試研報D $2: 1 \sim 17$

3 ）大場正明(1989年)：茶樹の更新方法とそ の後の生育収量および品質への影響, 静 岡県茶試研報第14号 $11 \sim 16$

4) 森山新三郎：茶樹中切り後の再更新効果 の持続年数, 茶研報第 84 号 (別冊) 14 15 